\title{
BRAF NM_004333.4:C.1790T>G
}

National Cancer Institute

\section{Source}

National Cancer Institute. BRAFNM 004333.4:C.1790T>G. NCI Thesaurus. Code C98333.

A nucleotide substitution at position 1790 of the coding sequence of the BRAF gene where thymine has been mutated to guanine. 